\title{
Professional Development for Primary School Teachers in Cameroon: Is the Cascade PD Model Effective?
}

\author{
André Moulakdi, Yamina Bouchamma \\ Department of Educational Foundations and Practices, Laval University, Quebec, Canada \\ Email: andre.moulakdi.1@ulaval.ca
}

How to cite this paper: Moulakdi, A., \& Bouchamma, Y. (2020). Professional Development for Primary School Teachers in Cameroon: Is the Cascade PD Model Effective? Creative Education, 11, 1129-1144. https://doi.org/10.4236/ce.2020.117084

Received: June 17, 2020

Accepted: July 25, 2020

Published: July 28, 2020

Copyright (๑) 2020 by author(s) and Scientific Research Publishing Inc. This work is licensed under the Creative Commons Attribution International License (CC BY 4.0).

http://creativecommons.org/licenses/by/4.0/

\section{(c) (i) Open Access}

\begin{abstract}
Teacher professional development (TPD), a constant concern on the minds of education leaders, is conducted in various ways in education systems around the world. Using Guskey's professional development assessment model, we evaluated a cascade model of teacher professional development in Cameroon's primary education system by examining the responses of the teachers who experienced these activities. Our findings indicate that the professional growth activities undertaken in cascade format, particularly professional development (PD) days, teacher evaluations, demonstration and group lessons did not adequately address the teachers' training needs and expectations and this because this model of training is not suitable to improve teaching practices in the context.
\end{abstract}

\section{Keywords}

Professional Development, Primary Teachers, Cascade Model, Cameroon

\section{Introduction}

Teacher professional development is an ever-present concern in today's education systems and comes in many forms (Bautista \& Ortega-Ruíz, 2015; Day \& Sachs, 2005; Borko, 2004). It is considered to be the ideal means to improve the quality of education (Coe et al., 2014; Desimone, 2009; Hattie, 2009) and constitutes a key element of the various ongoing educational reforms around the world (Kennedy, 2014; Karras \& Wolhuter, 2014; Villegas-Reimers, 2003).

The cascade model of professional development was first initiated as a workplace training programme as part of many United States war efforts during World War II (Jacobs \& Russ-Eft, 2001). The goal at the time was to rapidly 
train company leaders, who in turn would train their employees through an established hierarchy, to support production for military purposes (Dooley, 1945).

Also referred to as trainer training, the cascade model of professional development begins with the training of a group of leaders within an organisation. Following their training, these same individuals repeat the process by training their collaborators or colleagues (Jacobs, Russ-Eft, \& Zidan, 2001), and so on. This model is widely used in many types of organisations, including the education, health, and public sectors (Jacobs \& Russ-Eft, 2001). In education, this approach is deployed most often in teacher continuing development activities to introduce reforms or to implement new and effective teaching practices within the existing system (Mpho \& Matseliso, 2012).

In this top-down pyramidal training model for professional development, each level of training is referred to as a phase or stage (Karalis, 2016). The group of trainees in Phase 1 is generally composed of top-level experts within the organisation. This cohort of participants then becomes the trainers who initiate Phase 2 with the second level of employees and repeat this chain of operation down to the lowest layer of workers (Mpho \& Matseliso, 2012).

To ensure the effective implementation of this professional growth model, certain necessary criteria must be present. Hayes (2000) identified some of these required elements for success: the training approach, which must be much more experimental and reflective than transmissive; the training content, which must be open to interpretation, while avoiding rigid instructions with regard to work methods; the expertise, which must be widely disseminated through to every personnel level and not only within the chain of command; the involvement of a portion of the personnel in the preparation of the training programme and material; and there is an effective decentralisation of responsibilities within this structure.

According to Wedell (2005), context must be taken into account when introducing new knowledge through this training approach, which makes it more effective and sustainable. Considering the context should include vital follow-up activities for the teachers post-training as well as established support measures to enable teachers to not only apply what they have learned but also share this knowledge with others through discussion, collaboration, and interaction. Bax (2002) concurs that including a social and cultural dimension when implementing this model is essential for both its success and its effectiveness for the teachers involved.

Karalis (2016) identified four mandatory conditions for the successful use of this model: 1) The trainers' education level: Because the ultimate beneficiaries are teachers, to be able to effectively conduct a short-term training activity and transmit this knowledge, trainers must necessarily be academically superior; 2) formative and summative evaluations must be performed at each phase of the training programme (depending on the number of participants) to ensure that the quality of the activities remains down to the final person in the chain and is basically the same as that received by the initial trainers; 3 ) the active participa- 
tion of all who attend the training sessions; and 4) that the teachers' training needs be taken into account.

In a study involving primary educators in a few South African schools, Bax (2002) identified several issues associated with the use of the cascade model in two training initiatives. A group of South African teachers had travelled to Great Britain to undergo training in English teaching techniques, which they were mandated to transmit to their colleagues in certain schools attended primarily by black youth. The author observed a diluted and false interpretation of crucial information, in addition to a lack of confidence on the part of the colleagues participating in the training. Several factors related to the local context led to this lack of motivation: employee strikes, a lack of appropriate time and resources, the cultural difference with the host country, the lack of credibility of the training facilitators, and the lack of autonomy given to the participants by these facilitators.

Another study, conducted in India, focused on determining the most desirable characteristics of Phase 2 training facilitators and the role of experts in a cascading process of teacher professional development. In Phase 1, two experts were asked to train four pioneers who, in turn, had to train 154 teachers in four weeks. The authors of the study (Ngeze, Khwaja, \& Iyer, 2018) identified four requisite characteristics which the Phase 2 trainers had to have to successfully apply this professional growth model: 1) have a good understanding of the training content; 2) have they themselves attended training activities on the content they will be giving; 3 ) have attended training activities given by Phase 1 expert facilitators; and 4) know how to teach this training content and adequately master time management. These authors also stated that in the context of this training process, the experts must perform several tasks, such as: participate in the planning of the training activities; attend the training sessions to serve as mentors when required; and organise a follow-up meeting with the Phase 2 trainers following the training activity.

There are several notable advantages of using this teacher professional development model, such as the speed of the process and the number of beneficiaries involved, the level of flexibility, and the low cost-effectiveness ratio.

The cascade approach is the ideal strategy to reach the greatest number of individuals in a relatively short period of time when the size of the cohort is significant. This model also appears to be the most efficient solution when the participating teachers are dispersed and gatherings are difficult (Karalis, 2016; Jacobs, 2002; Cheese, 1986).

The cascade model can consist of several training techniques: lectures and presentations; workshops or discussion exercises; role-playing and simulations; and case studies and experimentation, to name a few, depending on the context. For training developers, this flexibility provides a wide range of pedagogical approaches to choose from (McDevitt, 1998; Karalis, 2016).

This model is presented as the most economical continuing development strategy for teachers in contexts where budget restrictions and cutbacks are evidenced, 
particularly low economic-status countries. Several authors agree that due to its low facilitator/trainee ratio, this model is the most effective (Leu, 2004; Day, 2000; Odden, Archilbald, Fermanich, \& Alix-Gallagher, 2002; Ono \& Ferreira, 2010).

Despite certain advantages, the cascade model does have its limitations, such as: the dilution and/or addition of new elements or modification of the training content as it is being transmitted to the participants (McDevitt, 1998; Hayes, 2000; Mpho \& Matseliso, 2012; Gilpin, 1997); the fact of not specifically addressing the teachers' basic pedagogical needs; and a loss of focus on the goals due to the hierarchical structure, when the trainers do not follow protocols and only provide a portion of the content (Bax, 2002).

In a study (Karalis, 2016) evaluating the cascade model used in the professional development of 10,000 adults, the Open University of Greece trained 12 Phase 1 facilitators who were then asked to train 20 persons each in Phase 2, for a total of 250 individuals who were dispersed thereafter throughout all of the Greek islands. The author revealed that these 250 facilitators were able to ultimately reach and train 8200 persons in a shorter period of time than what was first anticipated. The evaluation of the training programme showed that on a scale from 0 to 4 , the participants' level of satisfaction and interest in this training activity averaged 3.7. The author concluded that this training programme was successful because the majority of the trainers in each phase of the programme were able to transmit what they learned to others.

In 2012, Cameroon's Ministry of Basic Education developed a repository of standards for teacher professional development, accompanied by a new vision of pedagogical supervision. The purpose of the proposed reference guide was to reinforce the competencies of each stakeholder involved in the education process. In practical terms, these norms introduced a professional development strategy to complete, update, and modify existing teaching practices as well as to instigate new orientations in line with proposed education reforms. These changes were presented in a document describing strategies for growth and economic prosperity. In essence, this new vision of professional development was designed to:

- Establish objective scientific foundations for decision-making processes relative to teacher supervision and the pedagogical orientation of the system as a whole;

- Enhance teacher competency based on a preliminary assessment in each domain of the Teaching/Learning process;

- Supervise teachers to positively influence their performance and ultimately improve the quality of both teaching practices and student achievement.

This professional development reference protocol is divided into several levels, with each level constituting an essential element. Structured in top-down fashion, each superior level evaluates and guides the next one in the hierarchy, as follows: central level, followed by regional, departmental, district, and school level (kindergarten and primary), literacy centres, and finally informal basic education institutions. 
The central level is responsible for the quality of the pedagogy, the teaching practices, and the learning programmes for the entire country. It trains, guides, controls, and supervises the regional level and ensures that all of the regions employ the same teaching methods. The regional level continues the process by exercising these same dispositions at the departmental level, who in turn applies them in each district. The districts closely oversee their respective schools, principals, and teachers. The model is applied in most continuing development activities in the form of pedagogical days or sessions, teacher supervision, or teaching evaluations, among others, for the purposes of supporting and improving teaching practices and student results. According to the new standards, all of the activities must focus on the teacher who must constantly renew their pedagogical practices to ensure their students' academic success.

Lange (2016) conducted a quasi-experimental study comparing the effects of a primary teacher training programme in natural sciences and mathematics in the Anglophone private sector of Cameroon's primary education system using the cascade model. The effects of this training model on the teachers' practices and their students' outcomes were evaluated by means of questionnaires, video recordings, and the students' test results. The author thus compared the teaching practices of an experimental group of 176 teachers in eight private-sector primary schools with those of a control group of 67 teachers in five other schools, in addition to comparing the student outcomes in both groups. The results of the study showed that most of the teachers who had participated in the training programme were not only satisfied with the training they had received but also stressed the importance of this activity in regards to the following work-related aspects: the fact that it pertained to the didactics of two core subjects (natural sciences and mathematics); the use of teaching material; and classroom management. Also highlighted was the level of cooperation between the trainers and the participating teachers in the preparation of the training material. When comparing the practices of the teachers who attended the training programme and those in the control group, Lange (2016) observed a significant difference ( $p<$ 0.001 ), as the teachers in the experimental group were more prone to using didactic material in their teaching practices and solicited greater student participation in the learning activities (as encouraged in the programme) than what was observed in the control group. Indeed, when the teachers in the experimental group used their acquired techniques in teaching science and mathematics, it not only improved their practices but also, ultimately, their students' outcomes in these two subjects, compared to that achieved by the students in the control group.

In a study evaluating the cascade model of teacher professional development in Kenya, Kipkemoi Bett (2016) found only a slight increase in effectiveness relative to the improvement of the teachers' practices. Several possible causes were mentioned, including the time allotted for the training activities which appeared to relatively short, considering the amount of content involved; trainers who were chosen more by necessity than for their qualifications; trainers who failed to fully delve into all of the programme's content; and the inadequate preparation 
of the majority of participants who were primary school teachers in Kenya. Although the cascade model did manage to bring education leaders together to reach all of the teachers, Kipkemoi Bett (2016) argued that it failed to address the actual needs expressed by the teachers and their schools and that it was a mistake for some countries to assume that what was effective in developing countries would probably work in others. The author thus recommended using a school-centered professional development model that focused on meeting the teachers' actual needs.

Since Cameroon established its cascade model of teacher continuing development in primary schools, no evidence or official initiatives evaluating its impact on the improvement of teaching and learning have been recorded or published. Because of this serious lack of knowledge, education leaders and educators in the field have been unable to measure the actual effectiveness of this teacher training approach. As a result, teachers and their principals have no data to support their decision-making processes.

It is precisely for this reason that the present study was undertaken: to determine the impact of this cascade model for primary teacher professional development in the francophone sector of the Cameroon education system. Specifically, we sought to verify: 1) the level of primary teacher satisfaction with regard to the professional growth activities experienced through this cascade model and 2) whether the teachers' satisfaction was dependent on their personal characteristics.

\section{Requisites Prior to Evaluating the Teacher Professional Development Model}

Assessing a teacher continuing development model supposes that objectives were defined during its conception and that anticipated results were also clearly determined. Our review of the reform introduced by the Cameroon Ministry of Basic Education enabled us to identify the objectives of this new vision, which were to strengthen teacher competency and provide pedagogical supervision to enhance the quality of teaching practices and ultimately improve student achievement. This preliminary action enabled us to determine the most appropriate evaluation method for this study. The chosen method was therefore that of Guskey (2000), which served as our methodological framework.

This five-level linear approach addresses the factors related to both teacher satisfaction and student learning and is particularly well-suited for teacher continuing development. In practical terms, this evaluation method can be deployed following a teacher professional development programme based on the following five aspects: the participants' reaction; their learning level; the school's support of the designated changes; the amount of reinvestment of the acquired knowledge, know-how, and know-how-to-be, and finally, the impact on the students' learning outcomes.

\section{Level 1: Participants reaction}

In Guskey's (2000) model, the participants' reaction represents the first order 
of evaluation. In this study, we focused on their level of appreciation following a professional development activity. We thus gathered their opinions on various aspects of the programme, such as how the activity was presented and conducted; the training material used; the ability of the facilitator to transmit the new knowledge, etc. In short, we sought to determine whether the participants felt that this training activity was worthwhile.

\section{Level 2: Participants learning level}

After gathering the data relative to the participants' level of appreciation, this next level determined whether the training experienced enabled the participants to learn any new knowledge. In other words, were the participants able to assimilate the knowledge, know-how, and know-how-to-be presented during this training?

\section{Level 3: Organisational support for the proposed reforms}

In level 3, we evaluated the involvement of the school in implementing the new practices or knowledge acquired by the participants. Did the school's leadership facilitate the integration of these anticipated changes? It is acknowledged that the absence of such support can seriously compromise the integration of this new knowledge as well as what was gained in the previous levels.

Level 4: Reinvestment of the acquired knowledge, know-how, and knowhow-to-be

Here, we verified how well the knowledge acquired during the training was integrated into the teachers' existing practices. Briefly, we sought to determine if what the participants learned during the activity was sufficiently reinvested into their professional practice. The teachers' responses enabled us to evaluate the level of reinvestment of the acquired knowledge.

\section{Level 5: Impact on the students learning outcomes}

This level concerned the ultimate goal of professional development: helping the student. In this study, we sought to ascertain whether the teachers' training had a positive influence on their students' learning and achievement. The teachers used their students' data to gauge whether or not their training had helped them improve their students' outcomes. In addition to the teacher questionnaire on student learning, Guskey (2000) noted that several other student learning assessment measures could be used to evaluate whether learning has improved, such as standardised tests, portfolios, report cards, among others.

\section{Methodology}

This study is part of a larger project using a teacher professional development model that is different from the one currently in use in the primary education system in Cameroon. This research project in fact served to diagnose the situation, a required step in all processes involving the introduction of change (Efron Efrat, \& Ravid, 2013). The evaluative approach utilised in the present study enabled us to evaluate the level of effectiveness of the cascade method in professional development by examining the opinions and reactions of its beneficiaries. 
The project was approved by the Université Laval Research Ethics Committee (CÉRUL).

\subsection{Participants}

The study was conducted in the department of Diamare in Cameroon's Far North province. The participants were 68 primary school teachers in Cycles 2 (grades 3 and 4) and 3 (grades 5 and 6) as well as 10 principals from 10 public-sector primary schools. The participants were responsible for a total of 4041 students.

\subsection{Data Collection}

Data collection was performed using a questionnaire based on the professional development evaluation methodology developed by Guskey (2000), which included: participants' reaction and learning level; the school's support of the anticipated changes; the reinvestment of the knowledge/know-how/know-how-tobe acquired during the training programme; and the impact on the students' outcomes. The participants were also asked to comment on the different types of professional development using a Likert-type scale (always, often, never, and does not apply).

\subsection{Data Analysis}

Our data analysis was performed using SPSS 20.0 statistical software. Descriptive and inferential statistics ( $\mathrm{t}$-test and correlations) were used to analyse the professional development activities in regards to the teachers' sociodemographic and socio-professional characteristics, namely, gender, number of years of teaching experience, number of years of service in the school, and highest academic level achieved.

\section{Results}

\subsection{Participants' Characteristics}

The participants' $(\mathrm{N}=78)$ analysed characteristics reveal that the majority of participants were contractual employees $(74.4 \%)$; the proportion of government-appointed employees was low (11.5\%); more than half of the participants had less than 10 years of teaching experience (51.3\%); and the majority were women (62.8\%) whose highest level of education was a Secondary Cycle 1 diploma (BEPC, 56.4\%). Table 1 summarises these characteristics.

\subsection{Participants' Appreciation of the Professional Development Activities Characteristics}

The main teacher professional development activities using the cascade model presented here were: professional development (PD) days, teacher supervision, teacher evaluations, group lessons, and demonstration lessons. The participants' reactions to each activity are presented, based on the continuing development evaluation model of Guskey (2000). 
Table 1. Participants' characteristics.

\begin{tabular}{cccc}
\hline & Characteristics & N & $\%$ \\
\hline \multirow{2}{*}{ Gender } & Male & 49 & 62.8 \\
& Female & 29 & 37.2 \\
\hline \multirow{2}{*}{ Status } & Government employees & 9 & 11.5 \\
& Contractuals & 58 & 74.4 \\
& Tutors & 11 & 14.1 \\
\hline \multirow{2}{*}{ Teaching experience } & 9 years or less & 40 & 51.3 \\
& 10 to 15 years & 19 & 24.4 \\
\hline \multirow{2}{*}{ Function } & 16 years or more & 19 & 24.4 \\
& Teachers & 68 & 87.18 \\
& Principals & 10 & 12.82 \\
\hline Highest academic & BEPC & 44 & 56.4 \\
level attained & Probatory (post-secondary) & 10 & 12.8 \\
& Bachelor & 14 & 17.9 \\
& Master (Licence) & 10 & 12.8 \\
\hline
\end{tabular}

\subsubsection{Participants' Reactions}

Although over 90\% (92.3\%) of participants confirmed having attended all of the professional development activities proposed by their supervisors, the majority (60\%) expressed their dissatisfaction with how these activities-particularly the PD days, the teacher evaluations, and demonstration lessons-were organised. It indeed appears that the manner in which the training programmes were organised did not meet their needs (65.4\%). A significant number of participants (83.3\%) justified their response by stating that except for pedagogical supervision, the supervisors never sought their input when planning pedagogical activities, and that the practical aspects of organising PD days followed no established effectiveness criteria.

\subsubsection{Participants' Learning Level}

According to the participants, the activities were not frequent enough (91\%) and failed to address their actual training needs (91\%). Indeed, most of the participating teachers $(66.7 \%)$ found that although the subjects discussed with their superiors during their pedagogical supervision helped them to improve their practices, this supervision was rare and thus did not help them (91\%) grow professionally.

\subsubsection{Organisational Support}

A majority of participants (66.7\%) recognised that while their schools offered an environment for discussion and sharing, these establishments never ensured follow-ups or reports of the training activities, and particularly the PD days. The same number of respondents (66.7\%) stated that their supervisors were often available when solicited and provided the help they needed (48.7\%). 


\subsubsection{Reinvestment}

The teachers (60.3\%) stated that the subjects they discussed with their pedagogical supervisor helped to improve their teaching practices but that the PD days (57.7\%), teacher evaluations (82.1\%), group lessons (89.7\%), and demonstrations (67.9\%), in the way they were organised, did not contribute to improving their teaching practices.

\subsubsection{Effects on Student Outcomes}

The participating teachers unanimously agreed that the professional growth activities, in their current format, did not lead to any real changes in their teaching practices and thus, indirectly, did not enhance their students' outcomes.

Correlation between the professional development activities and the teachers' sociodemographic and socioprofessional characteristics.

The correlation matrix between the "perceived quality" of the professional development activities and the teachers' personal characteristics shown in Table 2 indicates coefficient values lower than 0.7 for a level of significance lower than or equal to 0.05 .

These values thus indicate a non-significant correlation, with the exception of that between the perceived quality of the PD days and the perceived quality of teacher supervision $(r=0.700$; Sig. $=0.000)$, which was significant.

Table 2. Correlations between the professional development activities and the teachers' personal characteristics.

\begin{tabular}{|c|c|c|c|c|c|c|c|c|c|c|c|}
\hline & $\mathbf{N}$ & r \& Sig. & Gender & $\begin{array}{l}\text { Teaching } \\
\text { experience } \\
\text { (years) }\end{array}$ & $\begin{array}{l}\text { Years in } \\
\text { the school }\end{array}$ & $\begin{array}{l}\text { Highest } \\
\text { academic } \\
\text { level }\end{array}$ & PD days & $\begin{array}{c}\text { Teacher } \\
\text { supervision }\end{array}$ & $\begin{array}{c}\text { Teacher } \\
\text { evaluations }\end{array}$ & $\begin{array}{l}\text { Group } \\
\text { lessons }\end{array}$ & $\begin{array}{l}\text { Demo. } \\
\text { lessons }\end{array}$ \\
\hline Gender & 78 & $\begin{array}{c}\text { r } \\
\text { Sig. }\end{array}$ & 1 & & & & & & & & \\
\hline $\begin{array}{c}\text { Teaching } \\
\text { experience (years) }\end{array}$ & 78 & $\begin{array}{c}\mathrm{r} \\
\text { Sig. }\end{array}$ & $\begin{array}{c}-0.099 \\
0.387\end{array}$ & 1 & & & & & & & \\
\hline $\begin{array}{c}\text { Years } \\
\text { in the school }\end{array}$ & 78 & $\begin{array}{c}r \\
\text { Sig. }\end{array}$ & $\begin{array}{c}-0.093 \\
0.419\end{array}$ & $\begin{array}{c}0.382^{\star *} \\
0.001\end{array}$ & 1 & & & & & & \\
\hline $\begin{array}{c}\text { Highest } \\
\text { academic level }\end{array}$ & 78 & $\begin{array}{c}\mathrm{r} \\
\text { Sig. }\end{array}$ & $\begin{array}{l}0.102 \\
0.374\end{array}$ & $\begin{array}{l}0.061 \\
0.594\end{array}$ & $\begin{array}{c}-0.017 \\
0.881\end{array}$ & 1 & & & & & \\
\hline $\begin{array}{c}\text { Teacher } \\
\text { supervision }\end{array}$ & 78 & $\begin{array}{c}r \\
\text { Sig. }\end{array}$ & 0.137 & 0.118 & 0.031 & $\begin{array}{c}-0.008 \\
0.942\end{array}$ & $\begin{array}{c}0.700^{\star *} \\
0.000\end{array}$ & 1 & & & \\
\hline $\begin{array}{c}\text { Teacher } \\
\text { evaluations }\end{array}$ & 78 & $\begin{array}{c}\mathrm{r} \\
\text { Sig. }\end{array}$ & $\begin{array}{l}-0.02 \\
0.863\end{array}$ & 0.306 & 0.746 & 0.464 & 0.236 & $\begin{array}{c}0.293^{* *} \\
0.009\end{array}$ & 1 & & \\
\hline Group lessons & 78 & $\begin{array}{c}\mathrm{r} \\
\text { Sig. }\end{array}$ & 0.136 & 0.005 & $\begin{array}{c}-0.058 \\
0.616\end{array}$ & $0.232^{*}$ & $\begin{array}{c}-0.003 \\
0.976\end{array}$ & $\begin{array}{c}0.339^{\star *} \\
0.002\end{array}$ & $\begin{array}{c}0.545^{\star \star} \\
0.000\end{array}$ & 1 & \\
\hline Demo. lessons & 78 & $\begin{array}{c}\text { r } \\
\text { Sig. }\end{array}$ & 0.134 & 0.047 & 0.061 & $\begin{array}{c}-0.048 \\
0.674\end{array}$ & $\begin{array}{c}-0.289^{\star} \\
0.01\end{array}$ & $\begin{array}{c}-0.033 \\
0.777\end{array}$ & $\begin{array}{c}0.426^{* *} \\
0.000\end{array}$ & $\begin{array}{l}0.212 \\
0.062\end{array}$ & 1 \\
\hline
\end{tabular}

${ }^{*}$ The correlation is significant at 0.01 (bilateral); ${ }^{\star}$ The correlation is significant at 0.05 (bilateral). 


\subsection{Teachers' Appreciation by Gender}

To verify whether the perceived quality of the various professional development activities differed depending on the teachers' gender, Levene's equality of variances test (presented in Table 3) recorded a significant value $(p=0.021<$ $0.05)$. This result indicates that the variances were not the same according to gender for the teacher evaluations; for this aspect, the "quality perceived" by the teachers differed significantly between males and females. Because all of the other values were not significant $(p>0.05)$, we may conclude that aside from the teacher evaluations, the teachers' appreciation of the professional development training was the same for both males and females.

\subsection{Main Results}

At the conclusion of this study, the following important points were retained:

1) In a perspective of professional development, the manner in which the activities were organised did not suit the participating teachers;

2) The cascade method in the professional development activities failed to meet the training needs of the participating teachers;

3) Despite the fact that the schools (within their means) provided an environment facilitating exchange and discussion, they failed to provide teachers with the necessary resources to enable them to update their teaching practices;

4) The teaching supervisors were only available to teachers when called upon and rarely initiated the process;

5) Although the themes presented during the continuing development activities were designed to improve pedagogical practices, the frequency of these training sessions was insufficient to sustain improvements in both teaching practices and student achievement;

6) With the exception of the teacher evaluations, the teachers equally perceived the quality of the training activities, regardless of gender.

Table 3. Equality of variances and of means.

\begin{tabular}{|c|c|c|c|c|c|c|c|}
\hline \multirow[b]{2}{*}{ Perceived quality } & \multicolumn{3}{|c|}{$\begin{array}{c}\text { Levene's Test for } \\
\text { Equality of Variances }\end{array}$} & \multicolumn{4}{|c|}{ t-test for Equality of Means } \\
\hline & & $\mathrm{F}$ & Sig. & $\mathrm{t}$ & $\begin{array}{c}\text { Sig. } \\
\text { (2-tailed) }\end{array}$ & $\begin{array}{c}\text { Mean } \\
\text { Difference }\end{array}$ & $\begin{array}{l}\text { Std. Error } \\
\text { Difference }\end{array}$ \\
\hline \multirow{2}{*}{ PD days } & Equal var. assumed & 1.308 & 0.256 & 0.635 & 0.527 & 0.03941 & 0.06204 \\
\hline & Equal var. not assumed & & & 0.601 & 0.551 & 0.03941 & 0.06562 \\
\hline \multirow{2}{*}{$\begin{array}{c}\text { Teacher } \\
\text { supervision }\end{array}$} & Equal var. assumed & 0.077 & 0.782 & -1.502 & 0.137 & -0.09909 & 0.06598 \\
\hline & Equal var. not assumed & & & -1.482 & 0.144 & -0.09909 & 0.06684 \\
\hline \multirow{2}{*}{$\begin{array}{c}\text { Teacher } \\
\text { evaluation }\end{array}$} & Equal var. assumed & 5.578 & 0.021 & 0.173 & 0.863 & 0.00862 & 0.04981 \\
\hline & Equal var. not assumed & & & 0.162 & 0.872 & 0.00862 & 0.05310 \\
\hline \multirow{2}{*}{$\begin{array}{l}\text { Group } \\
\text { lessons }\end{array}$} & Equal var. assumed & 0.119 & 0.731 & -1.198 & 0.235 & -0.06122 & 0.05111 \\
\hline & Equal var. not assumed & & & -1.208 & 0.232 & -0.06122 & 0.05069 \\
\hline \multirow{2}{*}{$\begin{array}{c}\text { Demonstration } \\
\text { lessons }\end{array}$} & Equal var. assumed & 2.332 & 0.131 & -1.180 & 0.242 & -0.09754 & 0.08267 \\
\hline & Equal var. not assumed & & & -1.242 & 0.219 & -0.09754 & 0.07855 \\
\hline
\end{tabular}




\section{Discussion}

One of the goals of this study was to determine how well the teachers appreciated this cascade model of professional development training. Following our analyses using the Guskey (2000) evaluation method, we found that the majority of the participating teachers were not satisfied with how these professional growth activities were organised. This feeling of dissatisfaction expressed by the teachers may be explained by the fact that these training events (mainly the professional development (PD) days which were organised by gathering all of the personnel in one room during 2 - 3 days), did not constitute veritable learning experiences for these educators; hence the lack of appreciation. Indeed, even though the themes presented were relevant to teaching practices, they failed to truly address the basic practical needs of the teachers. This observation confirms the findings of Mpho and Matseliso (2012) who also pointed out this issue with the cascade model.

As for what the participants learned, most of the teachers in our study acknowledged that the subjects discussed with the supervisors during the professional development activities could improve their teaching practices but that these activities did not take place often enough to have any tangible impact on their practices.

Based on this result, we may assume that if what was experienced during the professional development activities had a positive effect on the teachers' practices, we would expect the frequency of these activities to increase and thus cover more aspects of these practices. This possibility should definitely be considered, as the highest level of education of the majority of the participating teachers (56.4\%) was a Secondary Cycle 1 diploma (BEPC), which appears to be a very low level to ensure a successful teaching career.

Our findings also demonstrate that while the schools did present a setting that favoured sharing and discussions, they failed to provide the necessary resources to their teachers to help them hone their teaching skills. According to Wedell (2005), organisational support is vital to the successful integration of new practices following teacher professional development training. In the case of Cameroon, it notably appears that the teachers in our study did not have access to these precious resources to effectively apply their newly acquired knowledge, thereby affecting the quality of their teaching practices. This situation was also marked by a lack of available teaching supervisors and of professional growth activities, which were in the form of PD days and were not true learning experiences for the teachers.

Furthermore, our study shows that the themes presented during the PD days, during teacher supervision, or even during the group lessons were indeed designed to improve teaching and learning but that unfortunately, the way these activities were organised did not actually translate to any concrete enhancement of pedagogical practices and student outcomes. This result may be explained by the fact that most of the professional development training activities grouped 
everyone together based on a cascade model, and that the entire group was subjected to content chosen by the supervising facilitators, even if it did not address the teachers' actual needs in terms of professional advancement. As a result, the teachers adopted a passive attitude throughout the entire experience which in fact appeared to contradict the criteria for success laid forth in Hayes' (2000) cascade model and its experimental, interactive, and reflective dimensions, among other aspects. Ultimately, the teachers' passiveness could but lead to two things, namely, a feeble reinvestment of the knowledge supposedly acquired during the training and no real improvement of their teaching practices.

Our findings also demonstrate that the cascade model of teacher professional development did not promote the improvement of student achievement. This result also appears to contradict that obtained by Lange (2016), who observed improved student outcomes in the Anglophone sector of Cameroon's education system. This contradiction may be justified by taking into account the social and cultural dimensions in the organisation of professional development activities, as suggested by Bax (2002). Indeed, this author showed that in Cameroon's Francophone sub-system, these social and cultural dimensions were not integrated by pedagogical supervisors into their teachers' continuing development programmes. This sub-system was also characterised by the low level of credibility of certain teaching supervisors, which was attributed to their lack of education and relevant skills, compared to those of the participants. Finally, the absence of refreshments made available for the participants during the group day sessions was also an issue.

\section{Conclusion and Perspectives}

The cascade model of teacher professional development currently used in the Francophone sector of Cameroon's primary education system appears to be, in the minds of its education leaders, the most effective strategy to reach the greatest number of teachers in a relatively short period of time. Unfortunately, the results of our study indicate that this model is not suitable to ensure effective teacher continuing development.

In light of these findings, education decision-makers must explore alternative professional development strategies that directly address and support the actual practical challenges of their teachers. Successful school-based approaches in teacher professional development, such as professional learning communities, have shown great promise in contexts such as these. Cameroon's primary education leaders should therefore welcome this winning work approach for more effective and sustainable teacher professional development. Furthermore, two significant pro-active measures should be envisaged: raising the academic standard when recruiting pre-service teachers and taking pedagogical competency into account when nominating teaching supervisors. These two actions can undoubtedly help improve the effectiveness of the cascade approach in teacher professional development. 
Our evaluation of the cascade model of teacher professional development did not take place following a particular continuing development programme but was based rather on previous teacher training sessions attended by the participants whose perceptions were analysed. This approach could be viewed as being limited if the participants' opinions had been influenced by certain factors, such as their work conditions. In addition, the number of teachers participating in this study is not representative of the total number of primary level teachers currently practicing in the Francophone sub-system. This study therefore does not enable us to generalise our findings on the national level and thus circumscribes interpretations on the local level. Further research involving a representative number of teachers will enable us to support or invalidate the results of the present study and to generalise the interpretations.

\section{Conflicts of Interest}

The authors declare no conflicts of interest regarding the publication of this paper.

\section{References}

Bautista, A., \& Ortega-Ruíz, R. (2015). Teacher Professional Development: International Perspectives and Approaches. Psychology, Society and Education, 7, 240-251. https://doi.org/10.25115/psye.v7i3.1020

Bax, S. (2002). The Social and Cultural Dimensions of Trainer Training. Journal of Education for Teaching, 28, 165-178. https://doi.org/10.1080/0260747021000005592

Borko, H. (2004). Professional Development and Teacher Learning: Mapping the Terrain. Educational Researcher, 33, 3-15. http://www.jstor.org/stable/3699979 https://doi.org/10.3102/0013189X033008003

Cheese, J. (1986). Cascading the Training. Programmed Learning \& Educational Technology, 23, 248-252. https://doi.org/10.1080/0033039860230309

Coe, R., Aloisi, C., Higgins, S., \& Lee, E. M. (2014). What Makes Great Teaching? Review of the Underpinning Research. London: The Sutton Trust.

Day, C. (2000). Stories of Change and Professional Development: The Costs of Commitment. In C. Day, A. Fernandez, T. E. Hauge, \& J. Møller (Eds.), The Life and Work of Teachers: International Perspectives in Changing Times (pp. 109-129). London: Falmer Press.

Day, C., \& Sachs, J. (2005). International Handbook on the Continuing Professional Development of Teachers. Berkshire: Open University Press.

Desimone, L. M. (2009). Improving Impact Studies of Teachers' Professional Development: Toward Better Conceptualizations and Measures. Educational Researcher, 38, 181-199. https://doi.org/10.3102/0013189X08331140

Dooley, C. R. (1945). The Training within Industry Report (1940-1945): A Record of the Development of Management Techniques for Improvement of Supervision-Their Use and the Results. Washington, DC: War Manpower Commission, Bureau of Training, Training within Industry Service.

https://www.allaboutlean.com/wp-content/uploads/2018/02/Training-Within-Industry -Report.pdf

Efron Efrat, S., \& Ravid, R. (2013). Action-Research in Education: A Practical Guide. New York: The Guilford Press. 
Gilpin, A. (1997). Cascade Training: Sustainability or Dilution? In I. McGrath (Ed.), Learning to Train: Perspectives on the Development of Language Teachers' Trainers (pp. 185-195). Hemel Hempstead: Prentice-Hall.

Guskey, T. R. (2000). Evaluating Professional Development. Thousand Oaks, CA: Corwin Press, Inc.

Hattie, J. A. C. (2009). Visible Learning: A Synthesis of over 800 Meta-Analyses Relating to Achievement. London: Routledge. https://doi.org/10.4324/9780203887332

Hayes, D. (2000). Cascade Training and Teachers' Professional Development. ELT Journal, 54, 135-145. https://doi.org/10.1093/elt/54.2.135

Jacobs, R. L. (2002). Institutionalizing Organizational Change through Cascade Training. Journal of European Industrial Training, 26, 177-182. https://doi.org/10.1108/03090590210422058

Jacobs, R. L., \& Russ-Eft, D. (2001). Cascade Training and Institutionalizing Organizational Change. Advances in Developing Human Resources, 3, 496-503. https://doi.org/10.1177/15234220122238427

Jacobs, R., Russ-Eft, D., \& Zidan, S. (2001). Institutionalizing Organizational Change through Cascade Training: Implications for HRD Research. In O. Aliaga (Ed.), Proceedings of the 2001 Annual Conference of the Academy of Human Resource Development (pp. 435-439). Baton Rouge, LA: Academy of Human Resource Development.

Karalis, T. (2016). Cascade Approach to Training: Theoretical Issues and Practical Applications in Non-Formal Education. Journal of Education \& Social Policy, 3, 104-108.

Karras, G. K., \& Wolhuter, C. C. (2014). International Handbook of Teacher Education Training and Re-training Systems in Modern World. Nicosia: Studies and Publishing.

Kennedy, A. (2014). Models of Continuing Professional Development: A Framework for Analysis. Professional Development in Education, 40, 336-351. https://doi.org/10.1080/19415257.2014.929293

Kipkemoi Bett, H. (2016). The Cascade Model of Teachers' Continuing Professional Development in Kenya: A Time for Change? Coagent Education, 3, 1-9. https://doi.org/10.1080/2331186X.2016.1139439

Lange, S. (2016). Achieving Teaching Quality in Sub-Saharan Africa. Empirical Results from Cascade Training. Wiesbaden: Springer.

https://doi.org/10.1007/978-3-658-14683-2

Leu, E. (2004). The Patterns and Purposes of School-Based and Cluster Teacher Professional Development Programs (EQUIP1 Working Paper No. 2). Washington DC: USAID. https://pdf.usaid.gov/pdf_docs/pnadd973.pdf

McDevitt, D. (1998). How Effective Is the Cascade as a Method for Disseminating Ideas? A Case Study in Botswana. International Journal of Educational Development, 18, 425-428. https://doi.org/10.1016/S0738-0593(98)00029-7

Mpho, M. D., \& Matseliso, L. M. (2012). Does the Cascade Model Work for Teacher Training? Analysis of Teachers' Experiences. International Journal of Educational Sciences, 4, 249-254. https://doi.org/10.1080/09751122.2012.11890049

Ngeze, L. V., Khwaja, U., \& Iyer, S. (2018). Cascade Model of Teacher Professional Development: Qualitative Study of the Desirable Characteristics of Secondary Trainers and Role of Primary Trainers. In Proceeding at the 26th International Conference on Computers in Education (pp. 755-760). Manila: Asia-Pacific Society for Computers in Education.

https://pdfs.semanticscholar.org/d8a5/2b1f4afc7c21a2b680f49e69cd3850bdfefa.pdf 
Odden, A., Archilbald, S., Fermanich, M., \& Alix-Gallagher, H. (2002). A Cost Framework for Professional Development. Journal of Education Finance, 28, 51-74. http://www.jstor.org/stable/40704157

Ono, Y., \& Ferreira, G. J. (2010). A Case Study of Continuing Teacher Professional Development through Lesson Study in South Africa. South African Journal of Education, 30, 59-74. https://doi.org/10.15700/saje.v30n1a320

Villegas-Reimers, E. (2003). Teacher Professional Development: An International Review of the Literature. Paris: IIPE-UNESCO.

http://unesdoc.unesco.org/images/0013/001330/133010e.pdf

Wedell, M. (2005). Cascading Training Down into the Classroom: The Need for Parallel Planning. International Journal of Educational Development, 25, 637-651.

https://doi.org/10.1016/j.ijedudev.2005.03.004 